\title{
Peningkatan Motivasi dan Hasil Belajar Siswa dengan Model Problem Based Learning Berbantuan Simulasi PhET di Kelas XI IPA-C SMAN 6 Kota Bengkulu
}

\author{
Rexi Agusmin, Nirwana, Nyoman Rohadi \\ Program Studi Pendidikan Fisika, JPMIPA FKIP Universitas Bengkulu \\ Jalan Raya Kandang Limun No 1 Bengkulu 38123 \\ E-mail : rexiagusmin48@gmail.com
}

\begin{abstract}
ABSTRAK
Penelitian ini termasuk penelitian tindakan kelas yang bertujuan untuk mengetahui peningkatan aktivitas belajar, motivasi belajar dan hasil belajar siswa. Subjek penelitian ini adalah seluruh siswa kelas XI IPA-C SMAN 6 Kota Bengkulu yang berjumlah 36 siswa. Hasil penelitian ini menunjukan bahwa jumlah skor rata-rata aktivitas belajar siswa siklus I sebesar 24 dalam kategori aktif, siklus II sebesar 29 dalam kategori aktif, dan siklus III sebesar 30 dalam kategori aktif. Motivasi belajar siswa sebelum mengikuti proses pembelajaran berada pada kategori rendah dengan skor rata-rata yaitu 44,15 , dan pada saat setelah mengikuti proses pembelajaran skor rata-rata motivasi belajar siswa meningkat menjadi 65,15 yang berada pada kategori tinggi. Hasil belajar kognitif siswa pada siklus I yaitu daya serap sebesar 73,05\% dan ketuntasan belajar sebesar 66,66\% (belum tuntas), pada siklus II diperoleh daya serap sebesar 77,77\% dan ketuntasan belajar sebesar $86,11 \%$ (tuntas), pada siklus III diperoleh daya serap sebesar $85,14 \%$ dan ketuntasan belajar sebesar $100 \%$ (tuntas). Berdasarkan hasil penelitian dapat disimpulkan bahwa penerapan model Problem Based Learning berbantuan simulasi $\mathrm{PhET}$ dapat meningkatkan aktivitas belajar, motivasi belajar dan hasil belajar siswa.
\end{abstract}

Kata kunci : Model Problem Based Learning, Simulasi PhET, Aktivitas Belajar, Motivasi Belajar Siswa, Hasil Belajar kognitif.

\begin{abstract}
This research was a classroom action research aimed to find out students' improvement of learning activity, learning motivation and learning outcome of physics subject. The subjects of this research were all students of XI IPA-C in SMAN 6 Kota Bengkulu with the total of 36 students. The results of this research showed that the total of average score of students' learning activity in cycle I was 24 categorized as active, cycle II was 29 categorized as active, and cycle III was 30 categorized as active. Students' learning motivation before following learning process was obtained the average score of 44.15 which was categorized as low, and after following the learning process, the average score of students' learning motivation was increased to 65.15 categorized as high. The students' cognitive learning outcome in cycle I, the absorption strength was $73.05 \%$ and the learning mastery was $66.66 \%$ (incomplete), in cycle II it was obtained the absorption strength of $77.77 \%$ and the learning mastery of $86.11 \%$ (complete), while in cycle III it was obtained the absorption strength of $85.14 \%$ and the learning mastery of $100 \%$ (complete). Based on the results, it can be concluded that the implementation of Problem Based Learning model assisted by PhET simulation can improve students' learning activity, learning motivation and learning outcome.
\end{abstract}

Keywords: Problem Based Learning Model, PhET Simulation, Learning Activity, Students' Learning Motivation, Cognitive Learning Outcomes.

\section{PENDAHULUAN}

Kurikulum 2013 yang saat ini diberlakukan menekankan pada proses pembelajaran yang berpusat pada siswa (student centered) dengan pendekatan saintifik yang dilakukan melalui 5 tahap yakni mengamati, menanya, mencoba, mengasosiasi dan mengkomunikasikan. Penerapan kurikulum 2013 dapat menggunakan model pembelajaran 
yang memiliki karakteristik tematik terpadu, seperti model pembelajaran Problem Based Learning, Discovery Learning, dan Project Based Learning [1].

Pada kelas XI IPA-C SMAN 6 Kota Bengkulu ditemukan masih rendahnya motivasi belajar siswa, hal itu terlihat saat proses pembelajaran banyak siswa yang kurang memperhatikan penjelasan yang diberikan dan keinginan untuk mengerjakan soal juga sangat rendah. Siswa beranggapan bahwa fisika merupakan pelajaran yang membosankan karena berbuhubungan dengan rumus dan perhitungan. Aktivitas belajar siswa juga masih kurang, hal ini ditunjukkan saat proses pembelajaran siswa malas untuk bertanya ataupun menjawab pertanyaan yang diberikan. Pembelajaran yang dilakukan dikelas masih konvensional serta didominasi oleh metode ceramah sehingga proses pembelajaran hanya berpusat pada guru dan siswa menjadi kurang aktif. Ketika diskusi kelompok, hanya 41,6 \% siswa yang serius mengikuti diskusi, siswa yang lain mendiskusikan hal-hal diluar topik pembicaraan sehingga membuat pemahaman terhadap topik tersebut menjadi kurang. Kenyataannya bahwa nilai rata-rata hasil belajar fisika siswa pada saat magang III adalah 68. Nilai tersebut masih dibawah kriteria ketuntasan minimal (KKM) yang ditetapkan yakni 75 .

Ketersediaan alat-alat praktikum masih sangat minim sehingga guru harus merancang suatu praktikum dengan alat-alat yang terbatas. Sementara kegiatan laboratorium bisa juga dilakukan melalui virtual lab, namun dalam proses pembelajaran guru belum optimum menerapkannya. Untuk menjawab permasalahan yang ditemukan, maka dilakukan pembelajaran dengan model problem based learning. Menurut Sani (2015) Problem Based Learning (PBL) adalah model pembelajaran yang berpusat pada siswa dan penyampaiannya dilakukan dengan cara memberikan suatu permasalahan, merumuskan pertanyaan, melakukan penyelidikan, serta membuka dialog atau diskusi [2]. Kelebihan dari model berbasis masalah, menurut Saiful dan Aswan dalam Nurlaila, dkk (2013) yaitu : (1) melatih siswa mendesain suatu penemuan, (2) melatih siswa berpikir dan bertindak kreatif, (3) melatih siswa memecahkan masalah yang dihadapi secara realistis, (4) melatih siswa mengidentifikasi dan melakukan penyelidikan, (5) melatih siswa menafsirkan dan mengevaluasi hasil pengamatan, (6) merangsang perkembangan berpikir siswa dalam menyelesaikan masalah yang dihadapi dengan cepat, (7) membuat pendidikan disekolah menjadi lebih relevan dengan kehidupan [3]. Penelitian Rahayu, dkk ( 2017) yang dilakukan di SMAN 01 Mukomuko menyatakan bahwa model problem based learning dapat meningkatkan aktivitas, motivasi dan hasil belajar siswa [4]. Adapun rumusan masalah dalam penelitian ini yaitu : (1) Bagaimanakah aktivitas belajar siswa dengan model Problem Based Learning berbantuan simulasi PhET di kelas XI IPA-C SMAN 6 Kota Bengkulu? (2) Bagaimanakah motivasi belajar siswa dengan model Problem Based Learning berbantuan simulasi PhET di kelas XI IPA-C SMAN 6 Kota Bengkulu? (3) Bagaimanakah hasil belajar kognitif siswa dengan model Problem Based Learning berbantuan simulasi PhET di kelas XI IPA-C SMAN 6 Kota Bengkulu?

\section{METODE PENELITIAN}

Jenis penilitian ini merupakan penelitian tindakan kelas (Classroom Action Research). Penelitian tindakan kelas adalah penelitian yang dilakukan pada sebuah kelas untuk mengetahui akibat tindakan yang diterapkan pada suatu subyek penelitian di kelas tersebut [5]. Penelitian ini dilaksanakan dengan 4 tahapan pada tiap siklus yaitu perencanaan, pelaksanaan tindakan, pengamatan dan refleksi.

Teknik pengumpulan data yang digunakan adalah observasi, angket dan tes siklus. Data yang diperoleh adalah aktivitas belajar siswa dan aktivitas guru, motivasi belajar siswa dan hasil belajar kognitif siswa.

Penilaian observasi aktivitas belajar siswa dan guru ditulis dengan interpretasi penilaian seperti tabel berikut. 
Tabel 1. Interval kategori penilaian aktivitas belajar siswa dan guru

\begin{tabular}{|c|c|}
\hline Interval & Kategori \\
\hline $10-16$ & Tidak aktif \\
\hline $17-23$ & Cukup aktif \\
\hline $24-30$ & Aktif \\
\hline
\end{tabular}

Penilaian angket motivasi belajar siswa ditulis dengan interpretasi penilaian seperti tabel berikut.

Tabel 2. Interval kategori penilaian motivasi belajar siswa

\begin{tabular}{|c|c|}
\hline Nilai rentang & Interpretasi penilaian \\
\hline $18-31$ & Sangat rendah \\
\hline $32-45$ & Rendah \\
\hline $46-59$ & Sedang \\
\hline $60-73$ & Tinggi \\
\hline
\end{tabular}

Teknik analisis data hasil belajar kognitif siswa dalam penelitian ini dengan mencari nilai rata-rata, Standar Deviasi (SD), Daya Serap (DS), dan Ketuntasan Belajar Klasikal (KB).

1. Nilai Rata - rata

$$
\bar{X}=\frac{\sum X}{N}
$$

Ket $: \bar{X}=$ Nilai rata-rata

$\sum X=$ Jumlah nilai peserta tes

$\mathrm{N}=$ Jumlah peserta tes

2. Standar Deviasi

$$
\mathrm{S}=\sqrt{\frac{(X-\bar{X})^{2}}{N-1}}
$$

Ket: $S=$ Standar deviasi

$\mathrm{X}=$ Nilai peserta didik

$\bar{X}=$ Nilai rata-rata

$\mathrm{N}=$ Jumlah peserta didik

3. Ketuntasan Belajar Klasikal

$$
K B=\frac{N^{\prime}}{N} \times 100 \%
$$

Ket : KB = ketuntasan belajar klasikal

$\mathrm{N}^{\prime}=$ jumlah siswa yang skornya $\geq 75$

$\mathrm{N}=$ jumlah siswa keseluruhan

4. Daya Serap

$$
D S=\frac{N S}{s x N I} \times 100 \%
$$

Ket $:$ DS = daya serap peserta didik

NS = Jumlah nilai seluruh peserta didik

$\mathrm{NI}=$ nilai ideal

$\mathrm{S}=$ adalah jumlah peserta tes [6].

Penilaian hasil belajar kognitif akan ditulis menggunakan skala penilaian 1-100 dengan predikat sebagai berikut.

Tabel 3. Predikat capaian hasil belajar kognitif

\begin{tabular}{|c|lc|}
\hline Skala & \multicolumn{2}{|c|}{ Predikat } \\
\hline$\geq 80$ & Tinggi & (A) \\
\hline $71-79$ & Sedang & (B) \\
\hline $61-70$ & Rendah & (C) \\
\hline$\leq 60$ & Sangat Rendah & (D) \\
\hline
\end{tabular}

\section{HASIL DAN PEMBAHASAN}

3.1 Hasil 


\subsubsection{Hasil Observasi Aktivitas Belajar Siswa}

Hasil observasi aktivitas belajar siswa dari siklus I sampai dengan siklus III dapat dilihat pada gambar 1 sebagai berikut :

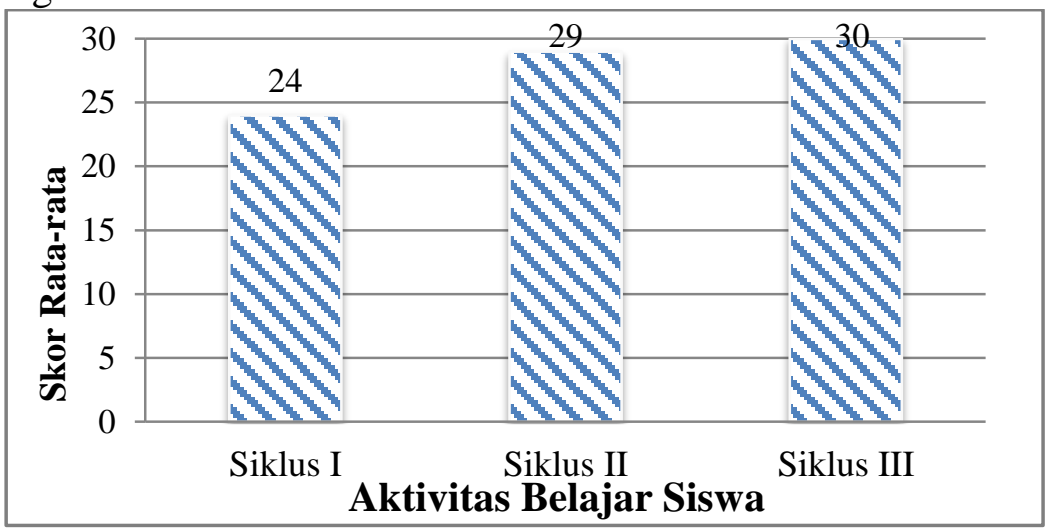

Gambar 1. Grafik Perkembangan Skor Rata-rata Aktivitas Belajar Siswa

\section{Hasil Motivasi Belajar Siswa}

Hasil motivasi belajar siswa sebelum mengikuti proses pembelajaran dan sesudah mengikuti proses pembelajaran dapat dilihat pada gambar 2 sebagai berikut :

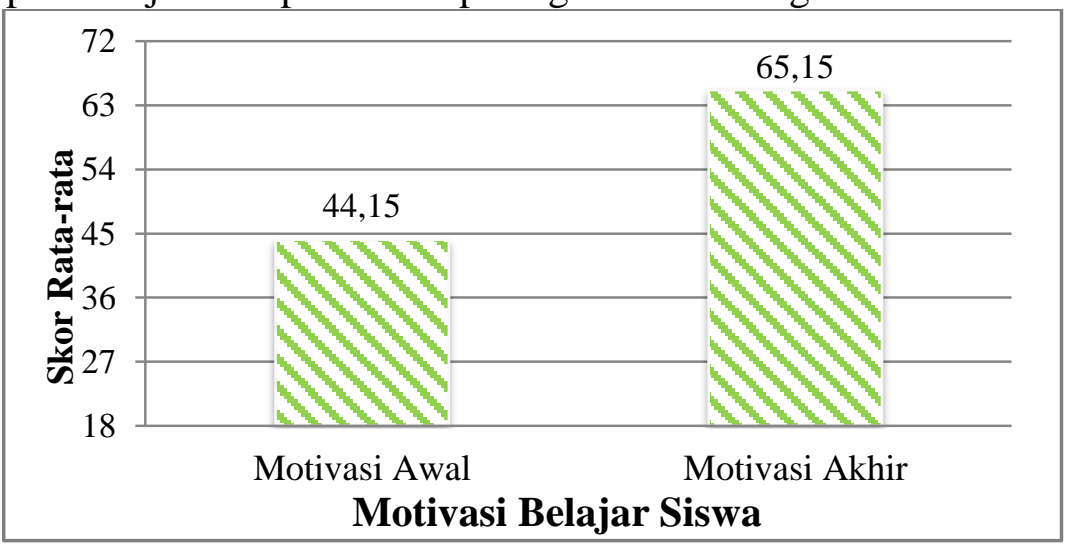

Gambar 2. Grafik Perkembangan Skor Rata-rata Motivasi Belajar Siswa

\section{Hasil Belajar Kognitif Siswa}

Hasil belajar kognitif siswa dari siklus I sampai dengan siklus III dapat dilihat pada gambar 3 sebagai berikut :

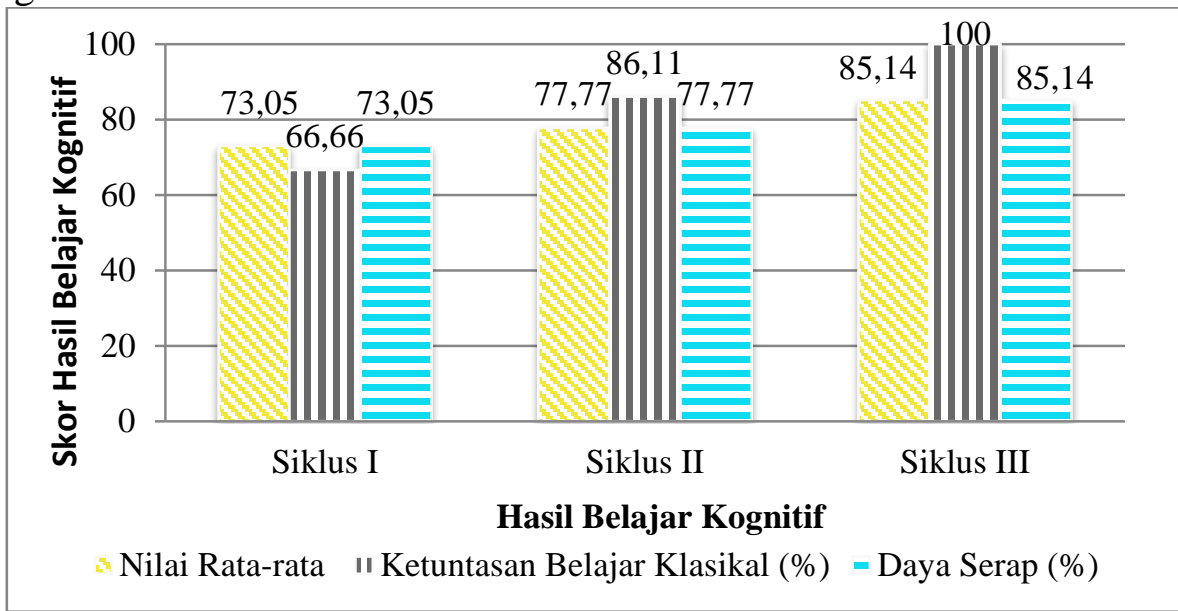

Gambar 3. Grafik Hasil Belajar Kognitif Siswa

\subsection{Pembahasan}

\subsubsection{Deskripsi Aktivitas Belajar Siswa}


Aktivitas belajar siswa meningkat dari siklus I sampai siklus III dimana secara keseluruhan berada pada kategori aktif. Skor rata-rata dua pengamat aktivitas belajar siswa pada siklus I sebesar 24 dalam kategori aktif dan meningkat pada siklus II dengan skor ratarata dua pengamat yaitu sebesar 29 dalam kategori aktif. Kemudian pada siklus III meningkat lagi dengan skor rata-rata dua pengamat sebesar 30 dalam kategori aktif dan telah mencapai skor maksimal.

Kekurangan-kekurangan aktivitas belajar siswa dalam mengikuti pembelajaran dianalisis dan dilakukan perbaikan setiap siklus. Peningkatan aktivitas siswa ini tidak terlepas oleh peranan guru dalam proses pembelajaran, dimana guru harus berupaya menciptakan kondisi lingkungan belajar siswa, mendorong siswa untuk belajar bahkan memberikan kesempatan kepada siswa untuk berperan aktif dalam proses pembelajaran. Hal ini sejalan dengan pendapat Sardiman yang menyatakan pembelajaran adalah serangkaian aktivitas yang dilakukan siswa guna mencapai hasil belajar tertentu di bawah bimbingan, arahan, dan motivasi guru [7].

Berdasarkan uraian diatas, aktivitas belajar siswa dalam mengikuti pembelajaran dangan penerapan model pembelajran inkuiri terbimbing telah mengalami peningkatan dan perbaikan setiap siklusnya.

\subsubsection{Deskripsi Motivasi Belajar Siswa}

Motivasi belajar siswa terdiri dari 6 indikator yaitu: 1) Adanya hasrat dan keinginan berhasil, 2) Adanya dorongan dan kebutuhan dalam belajar, 3) Adanya harapan dan cita-cita masa depan, 4) Adanya penghargaan dalam belajar, 5) Adanya kegiatan yang menarik dalam belajar dan, 6) Adanya lingkungan belajar yang kondusif [8]. Data motivasi belajar siswa diperoleh melalui pengisian angket motivasi belajar sebelum siswa mengikuti proses pembelajaran yaitu sebelum siklus I diaksanakan dan setelah proses pembelajaran yakni setelah siklus III dilaksanakan.

Motivasi awal siswa yakni sebelum mengikuti proses pembelajaran diperoleh skor ratarata sebesar 44,15 yang berada pada kategori rendah. Sedangkan motivasi akhir siswa yakni setelah mengikuti proses pembelajaran mengalami peningkatan skor rata-rata yaitu 65,15 yang berada pada kategori tinggi. Sebelum mengikuti proses pembelajaran motivasi belajar 10 siswa berada pada kategori sedang dan 26 siswa berada pada kategori rendah, sedangkan setelah mengikuti proses pembelajaran motivasi belajar 35 siswa berada pada kategori tinggi dan 1 orang siswa berada pada kategori sedang.

Motivasi belajar siswa mengalami peningkatan dikarenakan keinginan siswa untuk berhasil telah muncul dari dalam diri siswa seperti berusaha rajin belajar dan bertanya kepada guru mengenai materi yang belum dipahami. Siswa juga merasa adanya kebutuhan untuk memperoleh nilai belajar fisika yang baik dengan mengulang kembali materi yang diajarkan dirumah serta menyelesaikan tugas yang diberikan guru dengan sebaik-baiknya. Pujian yang diberikan guru membuat siswa menjadi lebih bersemangat dalam belajar karena mereka merasa dihargai dan dalam melakukan kegiatan percobaan menggunakan virtual lab membuat siswa tertarik untuk mengikuti pembelajaran.

Motivasi belajar siswa terlihat mengalami peningkatan. Hal ini sesuai dengan penelitian Rahayu (2017) yang menyatakan bahwa penerapan model Problem Based Learning dapat meningkatkan motivasi belajar siswa [4].

\subsubsection{Deskripsi Hasil Belajar Kognitif}

Pada siklus I perolehan nilai rata-rata siswa yaitu sebesar 73,05, ketuntasan belajar sebesar $66,66 \%$, dan daya serap sebesar $73,05 \%$ sehingga secara klasikal hasil belajar kognitif siswa belum tuntas dan siswa belum menguasai materi yang diajarkan. Ketuntasan belajar siswa atau jumlah siswa yang mendapat nilai akhir $\geq 75$ hanya 24 orang dengan persentase sebesar 58,33\% sedangkan kriteria ketuntasan belajar klasikal adalah apabila siswa yang mendapat nilai $\geq 75$ telah mencapai $75 \%$. Hal ini disebabkan karena siswa kurang memperhatikan penjelasan yang diberikan guru dan tidak maksimal ketika melakukan 
penyelidikan. Pada siklus II perolehan nilai rata-rata siswa meningkat menjadi 77,77 , ketuntasan belajar sebesar $86,11 \%$, dan daya serap sebesar $77,77 \%$ sehingga secara klasikal hasil belajar kognitif siswa pada siklus II sudah tuntas dan siswa telah menguasai materi yang diajarkan. Namun masih ada 5 siswa yang belum tuntas dengan nilai dibawah 75 .

Pada siklus III diperoleh nilai rata-rata sebesar 85,14, ketuntasan belajar sebesar $100 \%$, dan daya serap sebesar $85,14 \%$ sehingga secara klasikal hasil belajar kognitif siswa pada siklus III sudah tuntas dan terlihat jelas bahwa siklus III mengalami peningkatan dari siklus I dan II. Peningkatan itu terlihat dari perbandingan ketuntasan belajar klasikal siklus I dan II yang belum mencapai $100 \%$ dan pada siklus III ketuntasan belajar klasikal telah mencapai $100 \%$ dan seluruh siswa telah menguasai materi yang diajarkan.

Hasil belajar siswa juga ditentukan oleh peran seorang guru dalam proses pembelajaran. Peran guru sebagai motivator dan fasilisator dalam proses pembelajaran sangat membantu siswa dalam belajar [8]. Peningkatan hasil belajar ini terjadi karena guru telah melakukan perbaikan-perbaikan atas masalah yang masih ditemukan dalam proses pembelajaran. Hal ini sesuai dengan penelitian Meilesri (2017) yang menyatakan bahwa model Problem Based Learning dapat meningkatkan hasil belajar ranah kognitif siswa [9].

\section{KESIMPULAN DAN SARAN \\ 4.1 Kesimpulan}

Berdasarkan Penelitian yang telah dilaksanakan maka diperoleh kesimpulan yaitu (1) Penerapan model Problem Based Learning berbantuan simulasi PhET pada konsep gelombang cahaya dapat meningkatkan aktivitas belajar siswa di kelas XI IPA-C SMAN 6 Kota Bengkulu, pada siklus I terlihat 5 aspek berada pada kategori aktif, kemudian dilakukan refleksi, pada siklus II terjadi peningkatan aktivitas belajar siswa yakni 9 aspek berada pada kategori aktif, kemudian dilakukan refleksi dan pada siklus III yakni semua aspek aktivitas belajar siswa berada pada kategori aktif, (2) Penerapan model Problem Based Learning berbantuan simulasi PhET pada konsep gelombang cahaya dapat meningkatkan motivasi belajar siswa di kelas XI IPA-C SMAN 6 Kota Bengkulu, sebelum mengikuti proses pembelajaran motivasi belajar siswa berada pada kategori rendah dengan rata-rata memilih tidak setuju atas pernyataan yang diberikan dan setelah mengikuti proses pembelajaran motivasi belajar siswa berada pada kategori tinggi dengan rata-rata memilih sangat setuju atas pernyataan yang diberikan, (3) Penerapan model Problem Based Learning berbantuan simulasi PhET pada konsep gelombang cahaya dapat meningkatkan hasil belajar siswa di kelas XI IPA-C SMAN 6 Kota Bengkulu terlihat, pada siklus I ketuntasan belajar individu mencapai 24 siswa dan ketuntasan belajar klasikal berada pada kategori tidak tuntas, pada siklus II ketuntasan belajar individu mencapai 31 siswa dan ketuntasan belajar klasikal berada pada kategori tuntas, meningkat pada siklus III ketuntasan belajar individu mencapai 36 siswa dan ketuntasan belajar klasikal berada pada kategori tuntas.

\subsection{Saran}

Sebelum proses pembelajaran dilaksanakan maka disarankan untuk (1) Memahami langkah-langkah model Problem Based Learning serta dapat mengatur waktu dalam proses pembelajaran, (2) Mengecek persiapan yang diperlukan dalam pembelajaran seperti perangkat pembelajaran yang akan digunakan, (3) Menguasai dan mencoba terlebih dahulu media pembelajaran sebelum digunakan dalam proses pembelajaran.

\section{DAFTAR PUSTAKA}

[1] Sofyan, H., \& Komariah, K. (2016). Pembelajaran Problem Based Learning dalam Implementasi Kurikulum 2013 di SMK. Jurnal Pendidikan Vokasi, 6(3), 260-271.

[2] Sani, R. A. (2015). Pembelajaran Saintifik untuk Implementasi Kurikulum 2013. Jakarta: Bumi Aksara. 
[3] Nurlaila, N., Suparmi, \& Sunarno, W. (2013). Pembelajaran Fisika dengan PBL Menggunakan Problem Solving dan Problem Posing Ditinjau dari Kreativitas dan Keterampilan Berpikir Kritis Siswa. Jurnal Inkuiri, Vol 2, No 2, 114-123.

[4] Rahayu, A. S., Lubis, I. S., \& Putri, D. H. (2017). Penerapan Model Pembelajaran Berbasis Masalah (Problem Based Learning) dengan Pendekatan Saintifik untuk Meningkatkan Aktivitas Belajar, Hasil Belajar Fisika dan Motivasi Belajar Siswa SMAN 01 Mukomuko. Jurnal Pembelajaran Fisika, Vol 1, No 1, 19-27.

[5] Trianto. (2011). Panduan Lengkap Penelitian Tindakan Kelas. Jakarta: Prestasi Pustaka.

[6] Sudijono, A. (2012). Pengantar Evaluasi Pendidikan. Jakarta: Rajawali Pers.

[7] Sardiman. (2014). Interaksi \& Motivasi Belajar Mengajar. Jakarta: PT Raja Grafindo Persada.

[8] Uno, H. B. (2011). Teori Motivasi dan Pengukurannya Analisis dibidang Pendidikan. Jakarta: Bumi Aksara.

[9] Meilesri, W. D. (2017). Penerapan Model Pembelajaran Berbasis Masalah (Problem Based Learning) dengan Pendekatan Saintifik untuk Meningkatkan Aktivitas Belajar, Hasil Belajar dan Sikap Ilmiah Siswa Sman 1 Seluma. Skripsi, 1-140. 